Japan. J. Med. Sci. Biol., 24, 251-255, 1971

\title{
JUVENILE HORMONE AND SYNTHETIC ANALOGUES : EFFECTS ON LARVAL MOULT OF SILKWORM, BOMBYX MORI
}

\author{
Tetsuya OHTAKI, ShIgeo TAKEUCHI* AND KenJi MORI** \\ Department of Medical Entomology, National Institute \\ of Health, Shinagawa-ku, Tokyo 141, and \\ * Zoological Institute, Faculty of Science and \\ ** Department of Agricultural Chemistry, The University \\ of Tokyo, Bunkyo-ku, Tokyo 113, Japan
}

(Received: June 15, 1971)

\begin{abstract}
SUMMARY : Morphogenetic activities of three synthetic compounds, $d l-\mathrm{C}_{18}$ Cecropia juvenile hormone and its two analogues, on larval-larval moult of Bombyx silkworms were evaluated. Allatectomized 4th instar larvae moulted into 5th instar after injection or topical application of a certain amount of each compound. $d l-\mathrm{C}_{18}$-Cecropia juvenile hormone was most active; the dosage required for $50 \%$ larval moult induction was only $0.12 \mu \mathrm{g}$ per insect by topical application. No defect was seen in the adults developed from 5th instar larvae induced by the treatment with these compounds. The results mean that a single treatment with each compound satisfactorily substituted the juvenile hormone secreting organ, corpus allatum.
\end{abstract}

\section{INTRODUCTION}

Following purification and identification of the juvenile hormone $(\mathrm{JH})$ from Cecropia male moths (Röller et al., 1967; Meyer et al., 1968), morphogenetic activities of the extracted $\mathrm{JH}$ and synthetic analogues were tested on many hemimetabolous (Wigglesworth, 1969; Hopkins et al., 1970) and holometabolous (Röller and Dahm, 1968; Sehnal and Meyer, 1968; Srivastava and Gilbert, 1968; Hsiao and Hsiao, 1969; Meyer et al., 1970) insects. In these experiments the activities were evaluated on unnatural morphogenesis such as excess larval moult of the last instar larvae or the formation of second pupae. Moreover, corpora allata of test insects often remained intact.

Therefore, to evaluate the activities of $\mathrm{JH}$ and $\mathrm{JH}$ analogues correctly, we chose allatectomized 4 th instar larvae of the silkworm as the experimental animal. It enabled us to study the natural action of $\mathrm{JH}$ and to know whether $\mathrm{JH}$ could really substitute the JH secreting organ, corpus allatum.

This paper deals with the activities of synthetic $\mathrm{C}_{18}$-Cecropia $\mathrm{JH}$ and two synthetic $\mathrm{JH}$ analogues upon larval-larval moult of silkworm and the relationship between the chemical structure and the activity is discussed.

\footnotetext{
大滝哲也（国立予防衛生研究所 衛生昆虫部）

* 竹内重夫 (東京大学理学部動物学教室)

** 森 謙治 (東京大学農学部農芸化学科有機化学教室)
} 


\section{MATERIALS AND METHODS}

Preparation of compounds: In the present experiments, three synthetic compounds, methyl 10, 11-oxido-trans, trans-7-ethyl-3, 11-dimethyl-2, 6, 10-dodecatrienoate (Compound I), stereoisometric mixture of $\mathrm{C}_{17}$-Cecropia juvenile hormone (Compound II) and $d l$ - $\mathrm{C}_{18}$-Cecropia juvenile hormone (Compound III), were tested. The skeleton formulae of these three compounds are shown in Fig. 1.

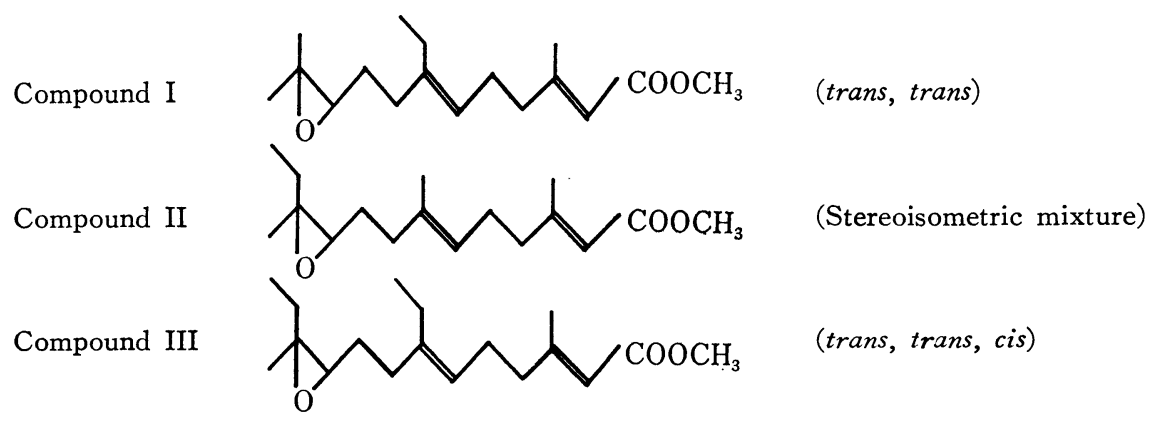

Fig. 1. Skeleton formula of compounds assayed for JH activities.

Procedures for syntheses of Compound I and II were already described in detail by one of the authors (Mori et al., $1969 \mathrm{a}, \mathrm{b}$ ). Compound III was synthesized by Loew et al. (1970).

Test animals and treatment of compounds: Fourth instar larvae of the silkworm, Bombyx mori, of $\mathrm{F}_{1}$ hybrid between two races, females of J. 122 and males of $\mathrm{C}$. 115 , were used. Twenty-four $\mathrm{hr}$ after the $3 \mathrm{rd}$ moulting at $25 \mathrm{C}$, the corpora allata were extirpated with sharpened forceps under a dissecting microscope. Three hr af ter the operation, a certain amount of each test compound dissolved in $0.5 \mu \mathrm{l}$ of peanut oil was injected with a $100-\mu l$ microsyringe controlled by a micrometer. The needles was pierced through the base of 4 th abdominal leg into the haemocoele near the base of 1st abdominal leg. By this manner, no injected oil leaked out from the puncture.

In another series of the experiments, peanut oil solution of the compound was diluted 10 -fold with redistilled acetone, and $5 \mu \mathrm{l}$ of the diluted solution was topically applied on the whole dorsal surface of each allatectomized larva.

After the treatment, the animals received immediately a plenty of fresh mulberry leaves, and were reared at $25 \mathrm{C}$. The body weights of the larvae at the time of the operation were 0.25 to $0.30 \mathrm{~g}$.

Evaluation of results: Effects of the compounds were evaluated after the next moulting. The most affected animals moulted into normal 5th instar larvae without any pupal characters. Less affected animals moulted into wide variety ranging from larval-pupal intermediate type to perfect precocious pupae. The effects were classified and scored as shown in Table 1.

Further observations were made until the treated animals became adults, and mating behavior and oviposition were also recorded. 
Table 1. Classification of the effects on metamorphosis

\begin{tabular}{ll}
\hline Score & \multicolumn{1}{c}{ States of metamorphosis } \\
\hline- & Perfect precocious pupae \\
+ & Pupal moult with larval character on cuticle or with imper- \\
& fect pupal development of mouthpart, wing and leg or with \\
& both of them \\
$H$ & Larval moult with partially pupal cuticle \\
H & Perfect 5 th instar larvae without pupal character \\
\hline
\end{tabular}

\section{RESUlts AND Discussion}

The results of the tests with three compounds are shown in Table 2. The most active substance was $d l-\mathrm{C}_{18}$-Cecropia JH (Compound III); the other two compounds also possessed high $\mathrm{JH}$ activities. As compared with the results on Galleria (Röller and Dahm, 1968), sensitivity of the silkworm to Compound III was almost 10 times higher in terms of dose per body weight. The difference may have resulted mainly from the development stage of the test animals; the last instar larvae were used in the Galleria test, while 4th instar larvae in the present experiments. In our preliminary experiments, much larger amount of $\mathrm{JH}$ was required to cause supernumeral larval moult on the last instar Bombyx larvae.

Compound I was less active than Compound II or III. This means that terminal ethyl group at $\mathrm{C}-11$ is important for such high $\mathrm{JH}$ activity. Replacement of the ethyl group at C-7 with a methyl group did not so strongly influence the activity; the activity of Compound II was half of that of Compound III on injection though the former is a stereoisometric mixture.

The activity of Compound III was expressed higher by topical application than by injection (Table 3). Similar results were reported by Bowers et al. (1965) in the assay of the $\mathrm{JH}$ activity of synthetic epoxy sesquiterpenoids on Teneblio. They interpreted that the lower activity by injection was due to rapid metabolic inactivation of injected substance, and that the higher activity by topical applicatoin to the slow partition of active material through the integument. By determining the activities of more than 30 of $\mathrm{JH}$ and $\mathrm{JH}$ analogues on Rhodnius, Wigglesworth (1969) stated that all but one epoxide sesquiterpenoids showed higher activity by injection than by topical application. In the present experiments, Compound I and II were shown to be less active by topical application as was the case on Rhodnius (Table 3). Such discrepancy in the assay of $\mathrm{JH}$ activity may have been due to the different species used, in which different rates of penetration of the active substances through cuticle or inactivation in insects or both might occur. Physical properties and localization of injected oil drops in haemocoele should also be considered.

The adults developed from 5th instar larvae, which were produced from the allatectomized 4th instar larvae treated with a sufficient amount of the active substances, did not show any detectable abnormality on both external morphology and behaviour. They displayed normal courtships and laid fertilized eggs.

Allatectomized 4th instar Bombyx larvae were used as test animals for the first 
Table 2. Effects of $\mathrm{JH}$ and $\mathrm{JH}$ analogues on Bombyx larvae:

Injection

\begin{tabular}{|c|c|c|c|c|c|c|}
\hline Compound & Dose ( $\mu \mathrm{g})$ & $\begin{array}{l}\text { No. of animal } \\
\text { tested }\end{array}$ & \multicolumn{2}{|c|}{ No. of animal } & \multicolumn{2}{|c|}{ transformed into } \\
\hline & 20 & 19 & 4 & 4 & 7 & 4 \\
\hline \multirow[t]{3}{*}{ I } & 10 & 20 & 9 & 3 & 3 & 5 \\
\hline & 5 & 20 & 20 & 0 & 0 & 0 \\
\hline & 10.0 & 17 & 0 & 0 & 0 & 17 \\
\hline \multirow[t]{3}{*}{ II } & 1.0 & 20 & 8 & 3 & 2 & 7 \\
\hline & 0.1 & 18 & 18 & 0 & 0 & 0 \\
\hline & 1.0 & 20 & 4 & 3 & 1 & 12 \\
\hline \multirow[t]{3}{*}{ III } & 0.5 & 20 & 9 & 2 & 5 & 4 \\
\hline & 0.25 & 17 & 13 & 2 & 1 & 1 \\
\hline & 0.10 & 19 & 19 & 0 & 0 & 0 \\
\hline \multicolumn{2}{|c|}{ Control (Peanut oil $0.5 \mu \mathrm{l}$ ) } & 20 & 20 & 0 & 0 & 0 \\
\hline
\end{tabular}

Topical application

\begin{tabular}{ccccccc}
\hline & 100 & 13 & 9 & 3 & 1 & 0 \\
I & 60 & 16 & 15 & 1 & 0 & 0 \\
& 30 & 17 & 16 & 1 & 0 & 0 \\
\hline \multirow{3}{*}{ II } & 10.0 & 21 & 0 & 0 & 4 & 17 \\
& 5.0 & 25 & 6 & 3 & 1 & 15 \\
& 2.5 & 13 & 6 & 2 & 3 & 2 \\
\hline \multirow{2}{*}{ III } & 0.5 & 16 & 1 & 0 & 1 & 14 \\
& 0.25 & 15 & 0 & 0 & 2 & 13 \\
& 0.125 & 16 & 7 & 0 & 0 & 9 \\
& 0.063 & 20 & 19 & 0 & 1 & 0 \\
Control (Peanut oil $0.5 \mu \mathrm{l})$ & 20 & 20 & 0 & 0 & 0 \\
\hline
\end{tabular}

Table 3. Comparison of $\mathrm{JH}$ activity by injection with that by topical application

\begin{tabular}{ccc}
\hline \multirow{2}{*}{ Compound } & \multicolumn{2}{c}{$\begin{array}{c}\text { Dose in } \mu g \text { /animal to give } \\
\text { allatectomized }\end{array} 4$ th $\begin{array}{c}\text { instar larval moult of } \\
\text { Bombyx larvae }\end{array}$} \\
\cline { 2 - 3 } & Injection & Topical application \\
\hline I & 14 & $>100$ \\
II & 1.2 & 0.12
\end{tabular}


time by Fukuda (1962) to demonstrate the endocrine activity of the transplanted corpora allata.

This test method was adopted by us for quantitative assay of $\mathrm{JH}$ activity and for obtaining basic knowledge on the biological effects of the synthetic substances. Performing the experiments, we realized that this method is very useful for its short duration, ease of determination and high sensitivity although producing a number of allatectomized larvae requires painstaking work.

\section{ACKNOWLEDGEMENT}

The authors are indebted to Dr. J. B. Siddall, Zoecon Corporation, California, for samples of synthetic $d l-\mathrm{C}_{18}-$ Cecropia juvenile hormone and to Dr. H. Akai, Sericultural Experiment Station, Tokyo, for supply of silkworms.

\section{REFERENCES}

Bowers, W. S., Thompson, M. J. AND Uebel, E. C. (1965): Juvenile and gonadotropic hormone activity of 10-11 epoxy farnesenic acid methyl ester. Life Sciences, 4 (II), 23232331.

FUKUDA, S. (1962): Secretion of juvenile hormone by the corpora allata in pupae and moths of silkworm, Bombyx mori. Annot. Zool. Jap., 35, 199-212.

Hopkins, D. E., Chamberlain, W. F. AND Wright, J. E. (1970): Morphological and physiological changes in Bovicola limbata (Mallophaga: Trichodectidae) treated topically with a juvenile hormone analogue. Ann. Entomol. Soc. Am., 63, 1360-1363.

HSIAO, C. AND HSIAO, T. (1969): Insect hormone: Their effects on diapause and development of hymenoptera. Life Sciences, 8 (II), 767-774.

Loew, P., Siddall, J. B., Spain, V. L. AND Werthemann, L. (1970): A short stereoselective synthesis of Cecropia juvenile hormones. Proc. Nat. Acad. Sci. (US), 67, 1462-1464: experimental details. ibid, 67, 1824-1826.

Meyer, A. S., Schneiderman, H. A., Hanzman, E. And Ko, J. H. (1968): The two juvenile hormones from the Cecropia silkmoth. Proc. Nat. Acad. Sci. (US), 60, 853-860.

Meyer, A. S., Hanzman, E., Schneiderman, H. A., Gilbert, L. I. and Boyette, M. (1970): The isolation and identification of the two juvenile hormones from the Cecropia silkmoth. Arch. Biochem. Biophys., 137, 190-213.

MORI, K., OHKI, M., Stalla-Bourdillon, B., Matsui, M. ANd BONers, W. S. (1969): Synthesis of compounds with juvenile hormone activity. Part IV. Methyl ( \pm )-14-homojuvenate and its -cis isomer, Analogues of Cecropia juvenile hormone. Agr. Biol. Chem., 33, 17921794.

Mori, K., Stalla-Bourdillon, B., OHKI, M., Matsui, M. ANd Bowers, W. S. (1969): Synthese de composes d'activite hormone juvenile II. Tetrahedron., 25, 1667-1677.

RölleR, H., DAHM, K. H., SweEly, C. C. AND Trost, B. M. (1967): The structure of the juvenile hormone. Angew. Chem. Int. Ed. Engl., 6, 179-180.

RölleR, H. AND DAHM, K. H. (1968): The chemistry and biology of juvenile hormone. Rec. Progr. Hor. Res., 24, 651-678.

SEHNAL, F. AND MEYER, A. S. (1968): Larval-pupal transformation: control by juvenile hormone. Science, 159, 981-984.

SRIVAStAVA, U. S. AND GILBERT, L. I. (1968): Juvenile hormone: effects on a higher dipteran. Science, 161, 61-62

WIGGLESWORTH, V. B. (1969): Chemical structure and juvenile hormone activity: comparative tests on Rhodnius prolixus. J. Insect Physiol., 15, 73-94. 